ten this wrong by imagining a harmless but largely fictitious self-identity. With surfing as a multibillion dollar transnational industry that inserts itself into and exploits the most marginalized communities in the world (one recent study found that places with good waves contribute $\$ 50$ billion annually to the global economy), surf culture can no longer morally justify ignoring its impacts on these peoples and places. Empire in Waves is a wake-up call to this truth.

Dina Gilio-Whitaker

Center for World Indigenous Studies

\title{
Kojin Karatani, The Structure of World History: From Modes of Production to Modes of Exchange, Trans. Michael K. Bourdaghs (Durham and London: Duke University Press, 2014). 376pp. Paperback \$26.95.
}

Most modern academic disciplines have constructed a range of theories to help explain both the field itself, and the tools specialists use to analyze and understand it. In many disciplines this has led to the construction of broad consensual paradigms - models that help make sense of the otherwise confusing morass of processes and events. The same has not been true of the discipline of history, with one or two exceptions. Certainly, for much of the time history has been written, the genre of universal history has been highly esteemed, an approach that treats the affairs of the world as though they were those of a single whole, and which creates a thematic framework to demonstrate that a genuine understanding of the whole reveals something much more useful than just the sum of its constituent parts. During the nineteenth century, however, the rise of the nation-state led to the replacement of universal history with more specialized and tightly focused national and biographical histories. Yet ironically, during this same century, German philosophers such as Kant, Hegel, and particularly Karl Marx, were attempting to construct broad historical frameworks that fused the constituent parts of history into paradigms as broad and inclusive as nineteenth century scientific paradigms such as evolution by natural selection or geological uniformitarianism.

In The Structure of World History, Japanese philosopher Kojin Karatani offers a modern universal history that, very much in the spirit of Karl Marx, offers a framework for constructing a more equitable future as well as making sense of the past. Karatani criticizes increasing disciplinary specialization, which:

has resulted in the loss of any totalizing, systematic perspective for comprehending the structures in which politics, religion, philosophy and other dimensions are interrelated, as well as the abandonment of any attempt to find a way to supersede existing conditions (ix-x).

One of the strengths of this book then, particularly for historians working in the fields of world-systems, globalization studies, world history or big history, is that it offers a universal analysis of global systems that helps us better understand inter- 
actions between individuals and local communities, as much as between nations and trading blocks. In addition, although this book is certainly theoretical and paradigmatic, it is also rich with real world historical examples drawn from a wide range of periods and regions. This keeps it grounded in the actual processes of history in a way that Kant or Hegel were unable to do.

Marx, in rejecting the sort of top-down philosophical approach of his German predecessors, analyzed history through the framework of modes of production, that is the different economic systems that operated at various historical periods, and upon which the ideological superstructure of culture, religion, and governance that characterized those periods was built. As Karatani points out, this approach has caused all sorts of problems for Marxist historians, because modern history demonstrates that the nation and state clearly function as autonomous bases complementary to the economic, rather than simply as part of the superstructure. This conundrum has led some Marxists to overemphasize the autonomy of the ideological superstructure, and underemphasize the importance of the economic base.

Marx identified the main sequence of the modes of production as the primitive communal mode, the ancient mode, the feudal mode, and the capitalist mode. The capitalist mode alienated workers from their productive activity, from the products they were making, from one another, and from nature. The constant cycle of boom and bust, and the dehumanization of the workers in the system, would awaken in them, Marx believed, an awareness of the freedom they lack. Capitalists would be overthrown, and a new form of society would arise — that of communism — where individuals would act for the good of the whole.

Karatani refocuses on the economic dimensions of Marxist analysis, but replaces Marx's modes of production with modes of exchange (essentially mechanisms of commodity exchange).

Karatani identifies four different modes of exchange:

Mode A: the reciprocity of the gift.

Mode B: ruling and protection.

Mode C: commodity exchange.

Mode D: supersedes the others and arrives as a form of universal religion. Karatani's intention then, again very much in the spirit of Marx, is to offer a universal history that rethinks the materialist conception of history with the explicit aim of creating a blueprint for the replacement of the capital-nation-state triad through world revolution. Ultimately, he suggests, Mode C will be replaced by a new system that echoes and supersedes the more equitable reciprocity system of Mode A. Mode of exchange D is Karatani's vision of what will replace capitalist society. But unlike the Marxist vision of a new communist utopia in which all individuals act for the good of the community, Karatani's utopia is not a new system, but an extension of the best features of the three modes that have preceded it, especially of the more just exchange system that characterizes Mode A.

The Structure of World History is a fascinating and particularly useful book 
for those scholars who are interested in attempts to construct universal master narratives or paradigms that help make sense of the processes of human history-in the same way, for example, that big bang cosmology helps us understand the processes of the universe. In keeping with most universal histories, Karatani is not content to merely analyze the past; rather he is offering a way to engineer a better future by transcending "the capitalist social formation from within" (291), thus reminding us all of the real purpose of large-scale history-to help us understand where we have come from, and where we may be going. Ultimately though, one is left wondering if Karatani's vision of a more just and equitable future will prove just as elusive as that of Karl Marx.

Craig Benjamin

Grand Valley State University

\section{Kerryn Higgs, Collision Course: Endless Growth on a Finite Planet (Michi- gan: MIT Press, 2014). 416pp. Paperback \$19.95.}

There is a certain danger in an economist reviewing a book that dedicates a considerable number of pages convincing the reader that economists - at least those in the mainstream - do not know what they are talking about when it comes to the environment. Higgs' very readable book is less an account of the science behind the "limits to growth" debate and more a history of the political and economic structures that have granted economic growth priority over the environment. The debate over whether there are limits to growth is taken at the outset as being answered in the positive (despite long and continuing debate on this both inside and outside of economics) and the book then proceeds to explain why this truth has been ignored.

The author, Kerryn Higgs, sets out her stall early, using Marx’s concept of metabolic rift to link the internal functioning of capitalism to environmental deterioration. While the overarching blame lies with the requirements of the economic system itself, the author primarily concentrates on how this has played out in the Anglo nations of the US, UK and Australia during the post 1980 period. The book is divided into four sections. The first, "Growth and its Challengers," would perhaps better have been titled "economists against the environment," due to its focus on the hostile reception that anti-growth scholarship, particularly the Club of Rome's The Limits to Growth, received from the economics profession. This is not presented as a debate on a subject of genuine uncertainty. Rather, the harsh criticisms levelled at the Limits report, chronicled in entertaining detail, are framed as misguided attempts by economists to protect one of the fundamental dogmas of their profession.

The second section, "Chasing Growth", outlines how growth came to be the dominant policy goal around the world. Higgs traces the origins of growth as 